\title{
Tennis injuries: occurrence, aetiology, and prevention
}

\author{
B M Pluim, J B Staal, G E Windler, N Jayanthi
}

Br J Sports Med 2006;40:415-423. doi: 10.1136/bjsm.2005.023184

A systematic search of published reports was carried out in three electronic databases from 1966 on to identify relevant articles relating to tennis injuries. There were 39 case reports, 49 laboratory studies, 28 descriptive epidemiological studies, and three analytical epidemiological studies. The principal findings of the review were: first, there is a great variation in the reported incidence of tennis injuries; second, most injuries occur in the lower extremities, followed by the upper extremities and then the trunk; third, there have been very few longitudinal cohort studies that investigated the association between risk factors and the occurrence of tennis injuries (odds ratios, risk ratios, hazard ratios); and fourth, there were no randomised controlled trials investigating injury prevention measures in tennis. More methodologically sound studies are needed for a better understanding of risk factors, in order to design useful strategies to prevent tennis injuries.

See end of article for authors' affiliations

Correspondence to: Dr Babette M Pluim, Royal Netherlands Lawn Tennis Association, PO Box 1617 , 3800 BP Amersfoort Netherlands; bpluim@ euronet.nl

Accepted 22 January 2006 Accepted 22 January 2006
$\mathrm{T}$ ennis is a global sport, with participation in more than 200 countries affiliated with the International Tennis Federation. ${ }^{1}$ It is also a professional sport in which millions of dollars in prize money are at stake for both men and women players. In the Netherlands, it is the second most popular sport, with more than one million participants from a population of 16 million. ${ }^{2}$ Among Dutch women it is actually the most popular sport. ${ }^{3}$ In other European countries tennis also ranks high on the list of popular sports. $^{3}$

Like many other sports, playing tennis-at either a recreational, collegiate, or professional level-places participants at risk of injury. Though many injuries that occur in tennis are common to other sports, tennis does have a unique profile of injuries. ${ }^{4}$ Differences in equipment, biomechanics, and physical demands result in an injury profile that differs from other racquets and throwing sports. ${ }^{4}$ Sports injuries, including tennis injuries, are a common cause of disability and, in some cases, absence from work. ${ }^{5-7}$ This can have substantial socioeconomic consequences, both on a personal and a societal level. ${ }^{8}$ For these reasons it is important to develop effective measures for the prevention of tennis injuries.

To develop prevention strategies, both the incidence and severity of tennis injuries must be determined. The severity of an injury can be described on the basis of the nature of the injury, the duration and nature of treatment, time lost from sports participation or work, permanent disability, and cost. ${ }^{9}$ Another important step is to determine risk factors and other mechanisms that are associated with these injuries. ${ }^{910}$ This aetiological research entails understanding the causes of injury, with the goal that modification or removal of these causes can prevent the occurrence of the injuries. ${ }^{10}$ The next step consists of the formulation of preventive measures. ${ }^{10}$ These measures must be evaluated with regard to their effectiveness before implementation. Ideally, evaluation should include randomised controlled trials. ${ }^{10-12}$

Our aim in this review of published reports was to provide an overview of the available scientific knowledge on the occurrence, aetiology, and possibilities for prevention of tennis injuries. We asked the following three questions. First, what are the most common tennis injuries, based upon the reported prevalence and incidence figures? Second, what associated risk factors and mechanisms are described with regard to the aetiology of tennis injuries? And third, what is known about the efficacy of prevention efforts designed to reduce the occurrence of tennis injuries?

Another purpose of this review was to identify gaps in knowledge with respect to the occurrence, aetiology, and prevention of tennis injuries and to encourage further methodologically sound epidemiological research in this field.

\section{METHODS}

We undertook a literature search to retrieve potentially relevant articles published since 1966. The following electronic databases were explored: Pubmed (from 1966 to October 2005), Embase (from 1989 to October 2005), and Cumulative Index to Nursing and Allied Health Literature (CINAHL) (from 1982 to October 2005). A priori defined search terms (Medical subject heading (Mesh) and text words) that were used in this search were: "injury", "injuries", "prevalence", "incidence", "incidence density", "proportion", "distribution", "population", "aetiology", "etiology", "mechanism", "risk factor", "risk factors", "prevention" and "intervention". These terms were combined with "tennis". Reading titles and abstracts identified potentially relevant articles. Citation tracking of the articles retrieved was also performed to identify additional relevant articles.

To be included in this review studies had to meet the following inclusion criteria: they must contain data on tennis injuries; they must investigate the frequency of tennis injuries, the aetiology (for example, risk factors) of tennis injuries, the efficacy of prevention strategies, or a 
combination of these purposes; and they must have been published in English, German, or Dutch. Studies focusing on treatment for tennis injuries and literature reviews were excluded. For the purpose of this review we defined a tennis injury as a musculoskeletal problem requiring reduction or interruption of tennis activity for any length of time, with or without evaluation or treatment by a health care provider. ${ }^{13}$

We did not expect to find many cohort or randomised controlled studies in this field. Furthermore, with the expected heterogeneity in study designs and methods, we elected not to follow a formal meta-analytic approach. The studies retrieved were classified as case reports, laboratory studies, descriptive epidemiological studies, analytic epidemiological studies, or intervention/prevention trials. A similar approach was conducted earlier by Pollack et al ${ }^{14}{ }^{15}$ with regard to the available evidence for the prevention of softball injuries. For reasons of clarity we defined descriptive epidemiological studies a priori as cohort studies (either cross sectional or longitudinal), describing the frequency (that is, prevalence or incidence or both) of tennis injuries in a cohort or subcohort. Analytic epidemiological studies were defined as cohort studies (either cross sectional or longitudinal) which aimed to estimate a measure of association (that is, odds ratio, risk ratio, hazard ratio) between risk factors and the occurrence of tennis injuries. The results of the selected studies will be described and summarised to formulate answers to the research questions posed above. The emphasis lies on the results of descriptive and analytic epidemiological studies, and intervention/prevention studies rather than laboratory studies or case series and reports.

\section{RESULTS}

Our search in the Pubmed, Embase, and Cinahl databases resulted in, respectively, 1368, 1617, and 2460 potentially relevant hits. To identify appropriate papers for the present review, the titles and abstracts were read and, if considered relevant, selected by two persons (BMP and JBS). In cases of disagreement further discussion was undertaken to achieve consensus. We found 39 case reports, 49 laboratory studies, 28 descriptive epidemiological studies, three analytic epidemiological studies, and no intervention study which met the inclusion criteria of the present review. Table 1 provides an overview of the distribution of study type and body region within the relevant articles.

\section{Case reports}

Of the 39 case reports, 29 dealt with injuries of the upper extremity, ${ }^{16-44}$ eight with injuries of the lower extremity, ${ }^{45-52}$ and two with the trunk..$^{53}{ }^{54}$ Of the case reports, the most common condition in the upper extremity injury section was stress fractures (14 case reports). ${ }^{16-29}$ Stress fractures in the upper extremity included the metacarpals, hamate bone, radius, ulna, and humerus. The suggested causal mechanism involved repeated loading on the upper extremity during the tennis stroke, ${ }^{27} 28$ and included the impact of the racket butt against the palm of the hand, ${ }^{16-18}$ and high torsional stresses. ${ }^{25} 2728$
Vascular injury in the upper extremity was mentioned four times. ${ }^{32-35}$ Though an uncommon injury, it has also been reported in overhead batting and racquet sports. Vascular injury may result from compression of the large vessels in the axilla during the service motion, resulting in aneurysm formation. ${ }^{35}$ Distal embolisation may occur. ${ }^{34}$ Endothelial injury caused by repeated microtrauma to the hand by the racket was also reported..$^{32} 33$

Regarding the lower extremity, injuries were more equally distributed and included case reports on tendon injuries, ${ }^{46}{ }_{48}$ plantar fascia tears, ${ }^{49}{ }^{52}$ muscles tears, ${ }^{45}$ stress fractures,${ }^{47} 50$ and intra-articular knee injury. ${ }^{51}$

\section{Laboratory studies}

Forty nine laboratory studies were identified: 36 involved the upper extremity, ${ }^{55-90}$ six the lower extremity, ${ }^{91-96}$ three the trunk, ${ }^{97-99}$ and four the whole body. ${ }^{100-103}$ In the upper extremity articles, the following topics were discussed most often: range of motion (seven studies) ${ }^{55} 58$ 61-65 and strength

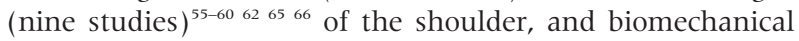
analysis of the stroke (six studies). ${ }^{69-71} 747577$

In the studies examining range of motion of the shoulder, internal and external rotation was measured using a goniometer. In $\operatorname{six}^{58}{ }^{61-65}$ of seven studies ${ }^{55}$ 58 $^{61-65}$, a significant decrease of internal rotation and total range of motion was demonstrated in the dominant arm. Kibler et a $l^{64}$ showed that the loss of total range of motion was progressive with age and years of tournament play.

Muscular strength of the shoulder was determined by isokinetic testing. Five ${ }^{58-606265}$ of seven studies $555658-606265$ showed an imbalance of muscle strength, with significantly greater isokinetic strength in the dominant arm than in the non-dominant arm for internal rotation, leading to a reduced external/internal rotation ratio. Both the loss of internal rotation motion and the muscle strength imbalance were hypothesised to increase the risk of shoulder injuries.

In three ${ }^{91}{ }^{95} 96$ of the six articles ${ }^{91-96}$ focusing on the lower extremity, the interaction between shoe and court surface was examined. The main conclusion of these studies was that lateral stability of the shoe is important in the prevention of injuries.

\section{Descriptive epidemiological studies}

Twenty eight descriptive epidemiological studies were identified, including 19 on tennis injuries in general, ${ }^{104-124}$ seven on injuries of the upper extremity, ${ }^{125-132}$ one on the lower extremity, ${ }^{133}$ and one on the trunk. ${ }^{134}$

\section{Injury incidence}

Injury incidence varied from $0.05^{122-124}$ to $2.9^{119}$ injuries per player per year (table 2). Per hour of play, the reported incidence varied from 0.04 injuries/1000 hours ${ }^{108}$ to 3.0 injuries/1000 hours. ${ }^{105}$ Incidence and prevalence rates for tennis elbow were quite high, with reported incidence varying from $9 \%^{128}$ to $35 \%{ }^{130}$ and prevalence varying from $14 \%{ }^{128}$ to $41 \% .^{131}{ }^{132}$

Table 1 Distribution of identified studies by type of study and body region

\begin{tabular}{lcclll}
\hline & Case studies & Laboratory & $\begin{array}{l}\text { Descriptive } \\
\text { epidemiological }\end{array}$ & $\begin{array}{l}\text { Analytical } \\
\text { epidemiological }\end{array}$ & $\begin{array}{l}\text { Intervention and } \\
\text { prevention }\end{array}$ \\
\hline General & 0 & 4 & 19 & 1 & 0 \\
Upper extremity & 29 & 36 & 7 & 0 & 0 \\
Lower extremity & 8 & 6 & 1 & 1 & 0 \\
Trunk & 2 & 3 & 1 & 1 & 0 \\
Total & 39 & 49 & 28 & 3 & 0 \\
\hline
\end{tabular}




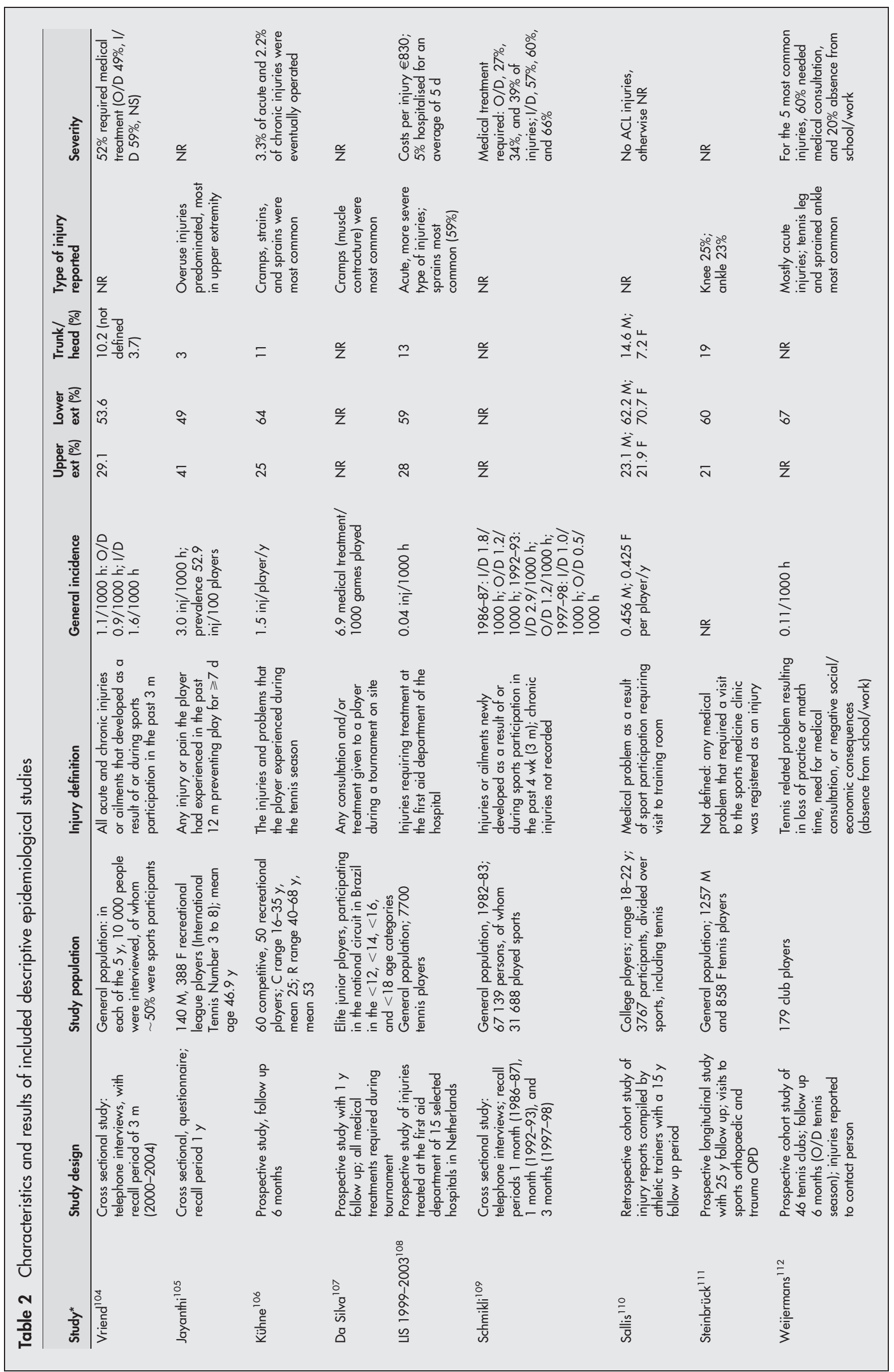




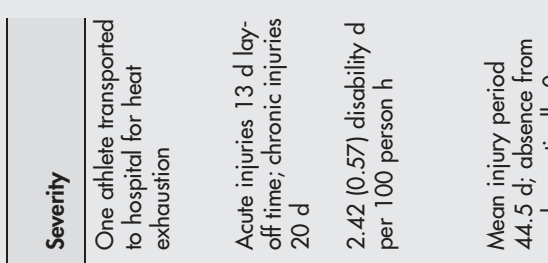

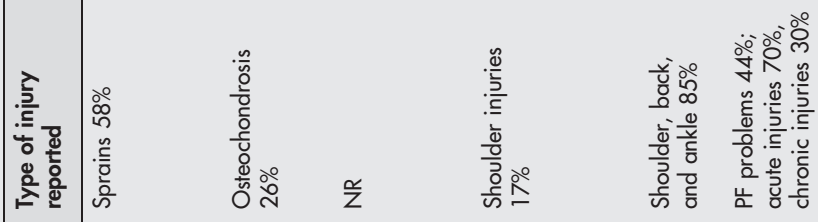

疍

홀

这势

흥흘

ล

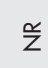

$\stackrel{o}{z}$

$=$

$\stackrel{a}{z} \quad \frac{o}{z}$

品

बे

$\stackrel{m}{\forall}$

艺学 字

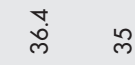

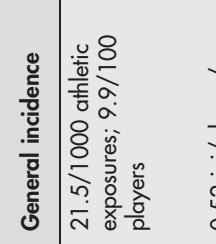

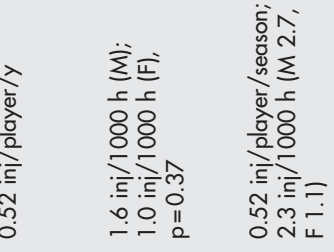

吝

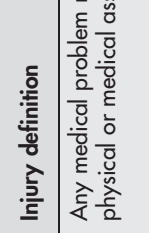

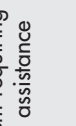

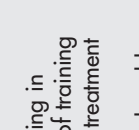

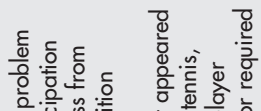

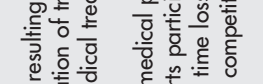

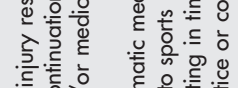

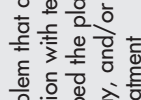

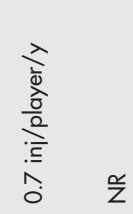

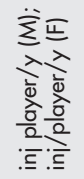

กิ่

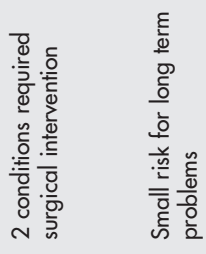

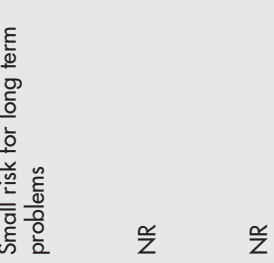

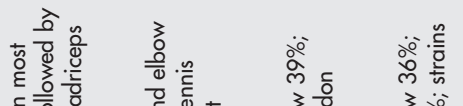

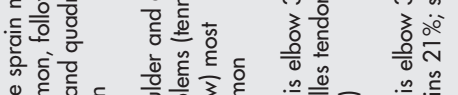

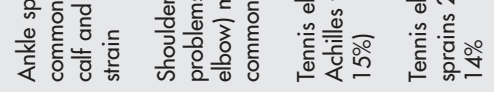

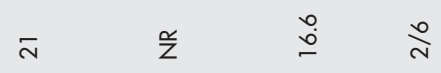

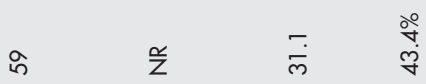

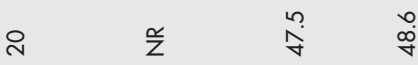

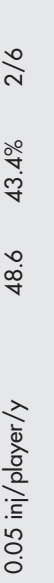

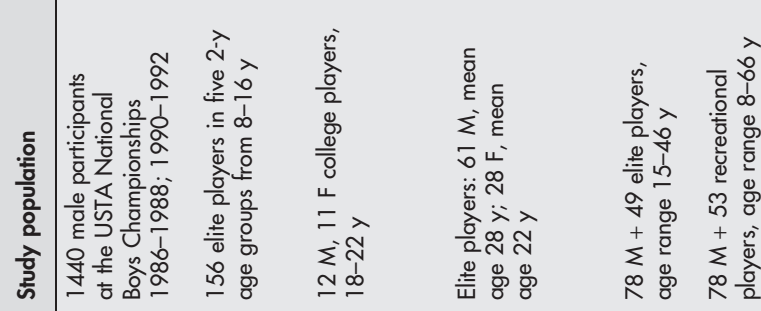

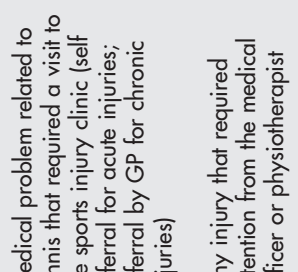

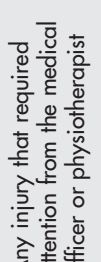

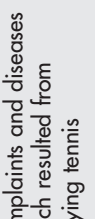

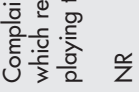

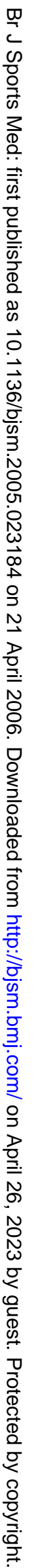

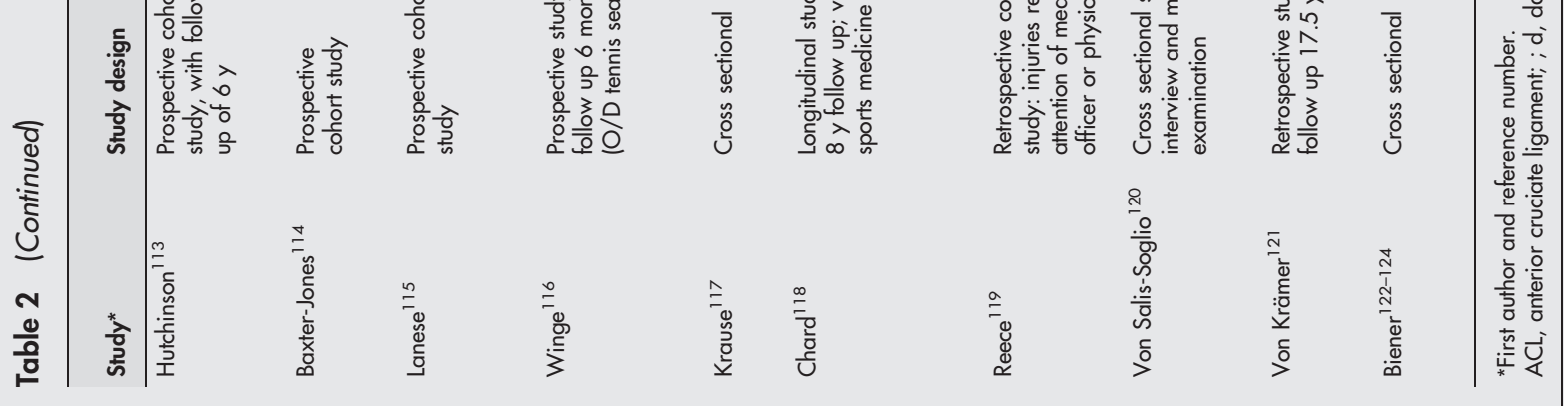


Table 3 Characteristics and results of included analytic epidemiological studies

\begin{tabular}{|c|c|c|c|c|c|c|}
\hline Study* & Study design & Study population & Risk factors & Outcomes & $\begin{array}{l}\text { Adjustment for } \\
\text { confounders }\end{array}$ & Results \\
\hline Llana $^{137}$ & $\begin{array}{l}\text { Cross } \\
\text { sectional } \\
\text { study }\end{array}$ & $\begin{array}{l}\text { A sample of } 146 \text { tennis } \\
\text { players in Spain selected } \\
\text { from a sample of } 4000 \\
\text { who had completed a } \\
\text { questionnaire on } \\
\text { "discomfort" associated } \\
\text { with tennis shoes }\end{array}$ & $\begin{array}{l}\text { Perceived design } \\
\text { errors }\end{array}$ & Discomfort & No & $\begin{array}{l}\text { Significant correlation }(p=0.02) \\
\text { between incorrect arch support } \\
\text { and plantar discomfort }\end{array}$ \\
\hline Spector $^{135}$ & $\begin{array}{l}\text { Retrospective } \\
\text { cohort study }\end{array}$ & $\begin{array}{l}81 \text { female ex-elite athletes } \\
\text { ( } 67 \text { middle and long } \\
\text { distance runners, and } 14 \\
\text { tennis players), aged } \\
40-65 \text {, recruited from } \\
\text { original playing records, } \\
\text { and } 977 \text { age matched } \\
\text { female controls from } \\
\text { London UK }\end{array}$ & $\begin{array}{l}\text { Long term weight } \\
\text { bearing sports } \\
\text { activity }\end{array}$ & $\begin{array}{l}\text { Pain } \\
\text { OA as defined } \\
\text { by radiological } \\
\text { changes (joint } \\
\text { space narrowing } \\
\text { and osteophytes) } \\
\text { in hip joints, PF } \\
\text { joints, and TF } \\
\text { joints }\end{array}$ & Yes & $\begin{array}{l}\text { The ex-athletes had greater rates } \\
\text { of radiological OA at all sites. This } \\
\text { association was strongest for the } \\
\text { presence of osteophytes at the TF } \\
\text { joints }(\mathrm{OR}=3.57(95 \% \mathrm{Cl}, 1.89 \\
\text { to } 6.71)) \text {, at the PF joints } \\
(\mathrm{OR}=3.50(1.80 \text { to } 6.81)) \text {, } \\
\text { narrowing at the PF joints } \\
(\mathrm{OR}=2.97(1.15 \text { to } 7.67)) \text {, femoral } \\
\text { osteophytes (OR }=2.52 \\
(1.01 \text { to } 6.26)) \text {, and hip joint } \\
\text { narrowing (OR = } 1.60(0.73 \text { to } \\
3.48)) \text {, and was weakest for } \\
\text { narrowing at } \\
\text { the TF joints (OR = } 1.17(0.71 \\
\text { to } 1.94)) \text {. The tennis players } \\
\text { tended to have more osteophytes } \\
\text { at the TF joints and hip }\end{array}$ \\
\hline $\mathrm{Nigg}^{136}$ & $\begin{array}{l}\text { Prospective } \\
\text { cohort study } \\
\text { ( } 2 \text { m follow } \\
\text { up) }\end{array}$ & $\begin{array}{l}171 \text { members of } \\
\text { tennis clubs }\end{array}$ & $\begin{array}{l}\text { Shoe, temperature, } \\
\text { type and duration } \\
\text { of match play, } \\
\text { subjective } \\
\text { assessment of shoe } \\
\text { comfort, sole grip } \\
\text { and lateral stability }\end{array}$ & Pain & No & $\begin{array}{l}\text { Stiffness of shoe and subjective } \\
\text { evaluation of frictional properties } \\
\text { of the shoe were significantly } \\
\text { associated with pain }\end{array}$ \\
\hline
\end{tabular}

Injury localisation

Ten ${ }^{104-106108110-113117119}$ of 13 studies ${ }^{104-106108}$ 110-113116 117 119 121-124 showed a preponderance of injuries of the lower extremity compared with the upper extremity.

\section{Injury type}

Four ${ }^{108} 112113118$ of six studies ${ }^{105} 108112113116118$ reported more acute than chronic injuries. Most acute injuries occurred in the lower extremities, whereas most chronic injuries were located in the upper extremities. Injuries to the trunk comprised 5\% to 25\% of all injuries. ${ }^{104-106} 108110111113$ 116-119 121-124

\section{Injury severity}

Injury severity was expressed in various ways in the different studies, including number of injuries requiring hospital admission $^{108113}$ or operative treatment, ${ }^{106}$ average medical costs per injury, ${ }^{108}$ time loss, ${ }^{114}{ }^{115}$ or the percentage requiring medical treatment. ${ }^{104} 109112$ Injuries sustained while playing indoors tended to be more severe than outdoor injuries, with a higher percentage requiring medical treatment. ${ }^{104}{ }^{109}$ In the study by Kuhne et al, $3.3 \%$ of acute and $2.2 \%$ of chronic injuries required surgery. ${ }^{106}$ Five per cent of the injuries in the Letsel Informatie Systeem (LIS) study required an average of five days of hospital admission. ${ }^{108}$ In the studies on juniors, injury severity was significantly less, with only one player of 1440 being taken to hospital and two injuries of 176 requiring surgery. ${ }^{113}$

\section{Sex}

Injury rates between men and women were compared in a prospective cohort study of intercollegiate tennis. ${ }^{115}$ In this study, 1.6 injuries per 1000 hours were recorded for male tennis players versus 1.0 injury per 1000 hours in female players. This was not a statistically significant difference $(\mathrm{p}=0.37)$.

Sallis et $a l^{110}$ studied injury patterns in 18-22 year old tennis players. This was a retrospective cohort study of injury reports compiled by certified athletic trainers. The incidence was 0.46 injuries per male player per year and 0.42 injuries per female player per year. The differences was not statistically significant.

Hutchinson et al $^{113}$ compared injury patterns in elite junior players (male and female) during a three year period (19961998) at the United States Tennis Association (USTA) tennis championships. There was no significant difference in the overall rate of injury (new and recurrent) between male and female players.

Winge $e a^{116}$ found a higher injury rate in men (2.7 injuries per 1000 hours) than in women $(1.1$ injuries per 1000 hours). This was a statistically significant difference $(\mathrm{p}<0.05)$.

\section{Age}

The Letsel Informatie Systeem ${ }^{108}$ is a continuous registration of injuries treated in the emergency departments of a selection of 15 hospitals and medical centres in the Netherlands. These injuries are generally acute and more serious. In this study, injury risk in tennis has been shown to gradually increase with age, from 0.01 injuries per player per year in the 6-12 year age group to 0.5 injuries per player per year in those over 75 years of age. An increased incidence with age was consistently shown for tennis elbow. ${ }^{127-132}$

\section{Level of play}

In these general descriptive epidemiological studies, the study populations can be characterised as recreational/ 
general, elite, or junior competitive. The studies include a wide distribution of retrospective, cross sectional, prospective cohort, and prospective longitudinal study designs. There were nine studies ${ }^{104-106} 108109111112118121$ involving recreational players or the general population, seven

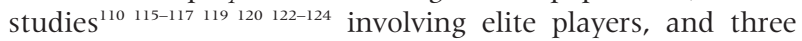
studies $^{107} 113114$ relating to junior tournament players. Study designs of junior and elite players often involved recording of injuries as medical consultations at tournaments or training centres. This method of injury reporting may inflate injury rates, therefore making it difficult to make direct comparisons with studies involving recreational players that often involve self reporting of their injuries.

We were able to identify only two studies that compared injury rates between players of different ability. Baxter-Jones et $a l^{114}$ studied elite young athletes. They found that performance success was significantly related to injury rate. Jayanthi et al ${ }^{105}$ described the incidence and prevalence of injuries in recreational players of different skill levels, ranging from International Tennis Number 3 to 8. Despite trends, there were no statistical differences in overall injury incidence and prevalence rates across all skill levels.

\section{Volume of play}

Studies describing the risks associated with volume of play are scarce. Increased playing time was associated with increased incidence of new cases of tennis elbow in recreational players playing more than two hours a day versus those playing less than two hours a day. ${ }^{128}$ However, total incidence and prevalence of all tennis related injuries was not different among recreational players who played less than four hours a week, four to six hours a week, or more than six hours a week. ${ }^{105}$

\section{Analytic epidemiological, and intervention studies}

Three studies were found that investigated risk factors for tennis injuries (table 3). Two of these ${ }^{135}{ }^{136}$ had a longitudinal study design and one ${ }^{137}$ was cross sectional. Adjustments for confounding variables was made in one longitudinal cohort study. ${ }^{135}$ The type of sports injury described in the investigated studies was variable and consisted of discomfort or pain from wearing tennis shoes, sport related injuries in general, low back pain, and osteoarthritis.

Llana et $a l^{137}$ described in a cross sectional study a significant correlation $(\mathrm{p}=0.02)$ between perceived incorrect arch support and plantar discomfort. Spector et al ${ }^{135}$ found that long term weight bearing sports activity was associated with the development of osteoarthritis.

No intervention study was retrieved investigating the effects of prevention measures on tennis injuries.

\section{DISCUSSION}

The principal findings of our study are first, that there is a great variation in the reported incidence rate of tennis injuries; second, that most injuries occur in the lower extremities, followed by the upper extremities and then the trunk; third, that there are very few cohort studies available that estimate a measure of association between risk factors and occurrence of tennis injuries; and fourth, that there are no randomised controlled trials on preventative measures in tennis.

The variation in the reported incidence rates of tennis injuries most probably reflects variation in injury definition, study design, populations under study, methods of data collection, and the duration of follow up or recall period. The lowest incidence rate (0.04 injuries per 1000 players per year) was reported in the LIS study. ${ }^{108}$ Injuries in this study included only those for which the player was treated at a hospital casualty department. This implies that predominantly more acute and serious injuries will be reported, as players with less serious and chronic injuries are more likely to visit their general practitioner, physiotherapist, or sports physician. The other study with a relatively low injury rate $(0.11 / 1000$ hours of play) was by Weijermans et al. ${ }^{112}$ In that study, injuries sustained by tennis players at a club had to be reported to a contact person in order to be recorded. This may have resulted in underreporting of injuries. Biener et al ${ }^{122-124}$ also reported a very low injury rate, which can be explained by their long recall period of 17.5 years.

The highest injury rates were found by Hutchinson et al ${ }^{113}$ and Silva et al. ${ }^{107}$ This is undoubtedly related to their rather inclusive injury definitions: "any medical problem that required physical or medical assistance"113 and "any consultation and/or treatment given to a player during a tournament on site", ${ }^{107}$ respectively. Using these definitions, injuries which may not have had any effect on tennis play, time loss, or work were also included. Kuhne et al addressed this problem by making a separate category for "Bagatellverletzungen" (minor injuries), which included sunburns, abrasions, and blisters. We were not able to find any study that identified the relation of match volume within a tournament or through a season and the risk of injury. Prospective studies of independent risks associated with increased playing time in junior tournament players are lacking and necessary in order to counsel parents, coaches, and tournament directors with appropriate evidence based recommendations.

Despite the wide variation of reported injury rates and study designs, comparisons of injury rates in tennis can be made with the rates in other sports. In order to make optimal comparisons, similar study designs and injury definitions should be used. There were 377 injuries in 456 matches involving all team sports studied during the 2004 summer Olympic Games. ${ }^{138}$ There was a total injury incidence of 0.8 injuries per match and 54 injuries per 1000 player matches, where injury was defined as any physical complaint incurred during the match that received medical attention regardless of consequence. Handball players (114/1000 player matches) and soccer players (108/1000 player matches) had the highest injury rates, while volleyball players (7.7/1000 player matches) had the lowest. With a similar definition of injury and comparable study design, Hutchinson et $a l^{133}$ reported 21.5 injuries/1000 athletic exposures and Silva et a $l^{107}$ reported 6.9 medical appointments/1000 games in prospective studies of junior national tournament tennis players.

It may be more appropriate to compare tennis with other individual non-contact sports rather than contact team sports. A retrospective cohort survey study in golfers reported 3.06 injuries/player injured in professional players of average age 36.5 years, and 2.07 injuries/player injured in amateur players of average age 47.2 years. ${ }^{139}$ This study did not report the total prevalence of injuries/100 players but had a total of 637 injuries in 703 golfers surveyed. In a cross sectional survey of recreational tennis players with an average age of 46.9 years, there were 299 injuries in 528 players giving a prevalence of 52.9 injuries/100 players. ${ }^{105}$ In a cross sectional survey study of recreational runners, $45.8 \%$ of 4358 male joggers sustained jogging injuries in the previous one year period. ${ }^{140}$ A prospective study of recreational runners training for a $10 \mathrm{~km}$ race reported that $29.5 \%$ of runners experienced an injury that caused at least some pain after exercise. ${ }^{141}$ Comparable prospective studies of recreational tennis players over a six month period reported injury rates of 0.11 / 1000 hours played ${ }^{112}$ and 1.5 injuries/player/year. ${ }^{106}$

Despite some variation in study design and definition of injury, tennis appears to have lower injury rates than contact team sports and also in some comparisons with non-contact individual sports such as golf and running. However, no 
known study has made direct comparisons between risks of injury or lifetime prevalence of injury between tennis and other sports.

Unfortunately, we were not able to identify any intervention studies on tennis injuries. An intervention study by Kibler et al, ${ }^{142}$ in which 51 tennis players undertook a specific programme of stretching exercises showed that the exercises improved the range of motion. Although they did not record the rate of injury, the authors hypothesised that this stretching programme would reduce injury risk. There is currently no evidence that limited flexibility is associated with an increased risk for tennis injuries. In a systematic review of intervention studies on the effect of stretching, Herbert and Gabriel ${ }^{143}$ showed that stretching before exercise did not result in a reduction of injury risk. However, they noted that generalisation of this conclusion required further testing. It therefore may be worthwhile to investigate the effects of the type of programme designed by Kibler et al ${ }^{142}$ on the occurrence of tennis injuries.

The aim of the present literature review was to provide an overview of available knowledge on the occurrence, aetiology, and prevention of tennis injuries. For practical reasons we refrained from doing a formal methodological quality assessment of individual studies or a quantitative data synthesis. However, by presenting studies with different study designs, a picture emerges that represents the current base of knowledge in this field. It is clear from the results that further studies on injury rates, risk factors, and prevention of tennis injuries are needed. Researchers should, if possible, choose a prospective study design in order to decrease the risk of recall bias.

A comparison of injury rates across studies will be facilitated when similar definitions of injuries are used and are clearly stated in the studies. The injury definitions in the studies in this review can be categorised as "time loss", "medical assistance", and "tissue injury" definitions. ${ }^{144} 145$ Each definition has advantages and disadvantages ${ }^{145}$ and delivers its own scope at the problem of tennis injuries. A clear benefit of using a "time loss" definition is that it will generally result in the recording of injuries which substantially affect the player's health or performance, or both. ${ }^{145}$

Few studies have been carried out on the reliability of injury recording systems, and this should therefore also be priority for future research. ${ }^{145-147}$ To improve the reliability of data collection it would be wise to use instruction manuals for observers. Another important epidemiological variable is exposure time. This is a measure of participation time in training and matches. It represents the amount of time the player is at risk of injury. The exposure time should, if possible, be recorded individually for each player. Individually recorded exposure times enable researchers to study risk factors in an advanced way by using a Cox proportional hazards regression model. ${ }^{148}$ However, because of practical limitations in many cases-especially in large cohort studies-estimates of exposure time must be used.

Currently, based on this literature review, we were unable to identify measures proven to prevent tennis injuries. There are no randomised controlled trials available, and the limited results of the studies on risk factors for tennis injuries fail to provide a clear perspective. Clinical experience and also the results of prevention studies in other sports ${ }^{114} 115$ suggest that physical training specifically targeting injury-prone movement patterns may lead to beneficial results. It would be very interesting to test the hypothesis put forward by Kibler associating loss of glenohumeral internal rotation (GIRD) and shoulder strength imbalance with an increased risk of shoulder injuries. ${ }^{142}$

Other possibilities for prevention include: education of players, parents, and coaches about tennis injuries, interval
What is already known on this topic

There is a great variation in the reported incidence rate of tennis injuries. Most injuries occur in the lower extremities, followed by the upper extremities and the trunk. Most acute injuries occur in the lower extremities, whereas most chronic injuries are located in the upper extremities.

\section{What this study adds}

By presenting studies with different study designs, a picture emerges that represents the current base of knowledge in this field. It is clear from the results that further studies on injury rates, risk factors, and prevention of tennis injuries are needed. A possible standard protocol for future studies is presented.

musculoskeletal screening of players to identify problem areas before injuries occur, and adjustment of equipment including shoes, racquets, strings, and balls as well as court surfaces. However, further research is needed to move from a stage of clinical expertise and speculation to real evidence based prevention of tennis injuries.

\section{Authors' affiliations}

B M Pluim, KNLTB, Amersfoort, Netherlands

J B Staal, Department of Epidemiology, Maastricht University,

Maastricht, Netherlands

G E Windler, ATP, Ponte Vedra Beach, Florida, USA

N Jayanthi, Loyola University Medical Center, Chicago, Illinois, USA

Competing interests: none declared

\section{REFERENCES}

1 ITF. http://www.itftennis.com/abouttheitf/nationalassociations/index.asp. Accessed 20 January 006

2 Breedveld K, Van der Meulen R, Harms L, et al. Rapportage Sport 2003. The Hague: Sociaal en Cultureel Planbureau, 2003.

3 Van Bottenburg M, Rijnen B, Van Sterkenburg J. Sports participation in the European Union. Trends and differences. Nieuwegein: Arko Sports Media, 2005

4 Pluim BM, Safran M. From breakpoint to advantage. Includes description, treatment, and prevention of all tennis injuries. Vista: USRSA, 2004.

5 Dekker R, Groothoff JW, van der Sluis CK, et al. Long-term disabilities and handicaps following sports injuries: outcome after outpatient treatment. Disabil Rehabil 2003;25:1153-7

6 Dekker R, Kingma J, Groothoff JW, et al. Measurement of severity of sports injuries: an epidemiological study. Clin Rehabil 2000;14:651-6.

7 Dekker R, van der Sluis CK, Groothoff JW, et al. Long-term outcome of sports injuries: results after inpatient treatment. Clin Rehabil 2003;17:480-7.

8 Stam P. Sportief bewegen en gezondheidsaspecten: een verkennende studie naar kosten en baten. Amsterdam: SEO, 1996.

9 van Mechelen W, Hlobil H, Kemper HC. Incidence, severity, aetiology and prevention of sports injuries. A review of concepts. Sports Med 1992;14:82-99.

10 Rivara FP. Introduction: the scientific basis for injury control. Epidemiol Rev 2003;25:20-3.

11 Olsen OE, Myklebust G, Engebretsen L, et al. Exercises to prevent lower limb injuries in youth sports: cluster randomised controlled trial. BMJ 2005;330:449.

12 Verhagen $\mathbf{E}$, van $\operatorname{der}$ Beek A, Twisk J, et al. The effect of a proprioceptive balance board training program for the prevention of ankle sprains: a prospective controlled trial. Am J Sports Med 2004;32:1385-93.

13 Maffulli N, Baxter-Jones AD, Grieve A. Long term sport involvement and sport injury rate in elite young athletes. Arch Dis Child 2005:90:525-7.

14 Pollack KM, Canham-Chervak M, Gazal-Carvalho C, et al. Interventions to prevent softball related injuries: a review of the literature. Inj Prev 2005; 11:277-81

15 Last J, ed. A dictionary of epidemiology, 3rd edition. New York: Oxford University Press, 1995.

16 Guha AR, Marynissen H. Stress fracture of the hook of the hamate. Br J Sports Med 2002;36:224-5.

17 Stark HH, Jobe FW, Boyes $\mathrm{JH}$, et al. Fracture of the hook of the hamate in athletes. J Bone Joint Surg Am 1977;59:575-82. 
18 Parker RD, Berkowitz MS, Brahms MA, et al. Hook of the hamate fractures in athletes. Am J Sports Med 1986;14:517-23.

19 Waninger KN, Lombardo JA. Stress fracture of index metacarpal in an adolescent tennis player. Clin J Sport Med 1995;5:63-6.

20 Murakami Y. Stress fracture of the metacarpal in a adolescent tennis player. Am J Sports Med 1988; 16:419-20.

21 Bespalchuk A, Okada K, Nishida J, et al. Stress fracture of the second metacarpal bone. Skel Radiol 2004;33:537-40.

22 Loosli AR, Leslie M. Stress fractures of the distal radius. A case report. Am J Sports Med 1991; 19:523-4.

23 Fragniere B, Landry $M$, Siegrist $O$. Stress fracture of the ulna in a professional tennis player using a double-handed backhand stroke. Knee Surg Sports Traumatol Arthrosc 2001;9:239-41.

24 Young CC, Raasch WG, Geiser C. Ulnar stress fracture of the non-dominant arm in a tennis player using a two-handed backhand. Clin J Sport Med 1995;5:262-4.

25 Bollen SR, Robinson DG, Crichton KJ, et al. Stress fractures of the ulna in tennis players using a double-handed backhand stroke. Am J Sports Med 1993;21:751-2.

26 Bell RH, Hawkins RJ. Stress fracture of the distal ulna. A case report. Clin Orthop Relat Res 1986;209:169-71.

27 Rettig AC. Stress fracture of the ulna in an adolescent tournament tennis player. Am J Sports Med 1983;11:103-6.

28 Rettig AC, Beltz HF. Stress fracture in the humerus in an adolescent tennis tournament player. Am J Sports Med 1985;13:55-8.

29 Sinha AK, Kaeding CC, Wadley GM. Upper extremity stress fractures in athletes: clinical features of 44 cases. Clin J Sport Med 1999;9:199-202.

30 Ishikawa H, Ueba Y, Yonezawa T, et al. Osteochondritis dissecans of the shoulder in a tennis player. Am J Sports Med 1988;16:547-50.

31 Retrum RK, Wepfer JF, Olen DW, et al. Case report 355: Delayed closure of the right olecranon epiphysis in a right-handed, tournament-class tennis player (post-traumatic). Skeletal Radiol 1986;15:185-7.

32 Nakamura T, Kambayashi J, Kawasaki T, et al. Hypothenar hammer syndrome caused by playing tennis. Eur J Vasc Endovasc Surg $1996 ; 11: 240-2$

33 Noel B, Hayoz D. A tennis player with hand claudication. VASA 2000;29:151-3.

34 Ikezawa T, Iwatsuka Y, Asano M, et al. Upper extremity ischemia in athletes: embolism from the injured posterior circumflex humeral artery. Int J Angiol 2000;9:138-40

35 Caiati JM, Masters CM, Todd EJ, et al. Symptomatic axillary artery dissection in a tennis player. Case report. Am J Sports Med 2000;28:411-12.

36 Birnbaum DA. Missed avulsion fracture of the lesser trochanter in a tennis professional. Med Trial Tech Q 1979;26:121-5.

37 Koob E, Steffens K. [True trigger wrist (a case report)]. Handchir Mikrochir Plast Chir 1988;20:188-290.

38 Burkhart SS. Os acromiale in a professional tennis player. Am J Sports Med 1992;20:483-4.

39 Dawson WJ. Sports-induced spontaneous rupture of the extensor pollicis longus tendon. J Hand Surg Am 1992;17:457-8.

40 Tsur A, Gillson S. Brachial biceps tendon injuries in young female high-level tennis players. Croat Med J 2000;41:184-5.

41 Prochaska V, Crosby LA, Murphy RP. High radial nerve palsy in a tennis player. Orthop Rev 1993;22:90-92.

42 Xarchas KC, Leviet D. Non rheumatoid closed rupture of extensor carpi ulnaris tendon. Report of a case in a professional athlete. Acta Orthop Belg 2002;68:399-402.

43 Faraj A, Rahman H, Norton R. Acute calcific tendinitis of abductor pollicis longus in a tennis player. Sports Exerc Inj 1998;4:138-9.

44 Berlemann U, al-Momani Z, Hertel R. Exercise-induced compartment syndrome in the flexor-pronator muscle group. A case report and pressure measurements in volunteers. Am J Sports Med 1998;26:439-41.

45 Rinn T, RCN. Medial gastrocnemius tear ("tennis leg"): a case report. J Sports Chiropr Rehabil 1996;10:37-40.

46 Lowry AW, McFarland EG, Cosgarea AJ, et al. Partial rupture of the quadriceps tendon in a tennis player. Clin J Sport Med 2001;1 1:277-9.

47 Hyde T, Kettner N, Epstein B. Concurrent stress fractures of the femoral shaft in a tennis player. J Neuromusculoskeletal Syst 1998;6:24-30.

48 Trepman E, Mizel MS, Newberg AH. Partial rupture of the flexor hallucis longus tendon in a tennis player: a case report. Foot Ankle Int 1995; 16:227-31

49 McElgun TM, Cavaliere RG. Sequential bilateral rupture of the plantar fascia in a tennis player. J Am Podiatr Med Assoc 1994;84:137-41.

50 Motto SG. Stress fracture of the lateral process of the talus - a case report. Br J Sports Med 1993;27:275-6.

51 Powell JM, Kavanagh TG, Kennedy DK, et al. Intra-articular knee injuries in racquet sports. A review of 128 arthroscopies. Surg Endosc 1988;2:39-43.

52 Herrick R, Herrick S. Rupture of the plantar fascia in a middle-aged tennis player. A case report. Am J Sports Med 1983;11:95.

53 Hofmann A, Weishaupt P. [High performance sports and backache: the value of functional analysis and progressive dynamic strength training of the trunk muscles. Case report of a 15-year-old high performance tennis player]. Sportverletz Sportschaden 1999;13:M7-9.

54 Mithofer K, Giza E. Pseudarthrosis of the first rib in the overhead athlete. Br J Sports Med 2004;38:221-2.

55 Stanley A, McGann R, Hall J, et al. Shoulder strength and range of motion in female amateur-league tennis players. J Orthop Sports Phys Ther 2004;34:402-9.

$56 \mathrm{Ng} \mathrm{L}$, Kramer J. Shoulder rotator torques in female tennis and nontennis players. J Orthop Sports Phys Ther 1991;13:40-6.
57 Mont MA, Cohen DB, Campbell KR, et al. Isokinetic concentric versus eccentric training of shoulder rotators with functional evaluation of performance enhancement in elite tennis players. Am J Sports Med 1994;22:513-17

58 Ellenbecker T. Shoulder internal and external rotation strength and range of motion of highly skilled junior tennis players. Isokinetics Exerc $S_{c}$ 1992;2:65-72.

59 Ellenbecker T. A total arm strength isokinetic profile of highly skilled tennis players. Isokinetics Exerc Sci 1991;1:9-21.

60 Pensivy S. In the game. Tennis shoulder: many tennis athletes have a shoulder syndrome that creates muscle strength imbalance. Adv Dir Rehabil 2002; 11:29-30.

61 Ellenbecker TS, Roetert EP, Bailie DS, et al. Glenohumeral joint total rotation range of motion in elite tennis players and baseball pitchers. Med Sci Sports Exerc 2002;34:2052-6.

62 Ellenbecker TS, Roetert EP. Effects of a 4-month season on glenohumeral joint rotational strength and range of motion in female collegiate tennis players. J Strength Cond Res 2002; 16:92-6.

63 Ellenbecker TS, Roetert EP, Piorkowski PA, et al. Glenohumeral joint internal and external rotation range of motion in elite junior tennis players. J Orthop Sports Phys Ther 1996;24:336-41.

64 Kibler WB, Chandler TJ, Livingston BP, et al. Shoulder range of motion in elite tennis players. Effect of age and years of tournament play. Am J Sports Med 1996;24:279-85

65 Ellenbecker T, Roetert EP. Age specific isokinetic glenohumeral internal and external rotation strength in elite junior tennis players. J Sci Med Sport 2003;6:63-70.

66 Ellenbecker TS, Roetert EP. Testing isokinetic muscular fatigue of shoulder internal and external rotation in elite junior tennis players. J Orthop Sports Phys Ther 1999;29:275-81.

67 Ellenbecker TS, Roetert EP. Isokinetic profile of elbow flexion and extension strength in elite junior tennis players. J Orthop Sports Phys Ther 2003;33:79-84.

68 Bernhang AM, Dehner W, Fogarty C. Tennis elbow: a biomechanical approach. J Sports Med 1974;2:235-60.

69 Elliott BC. Biomechanics of the serve in tennis. A biomedical perspective. Sports Med 1988;6:285-94.

70 Kibler WB. Biomechanical analysis of the shoulder during tennis activities. Clin Sports Med 1995; 14:79-85.

71 Blackwell JR, Cole KJ. Wrist kinematics differ in expert and novice tennis players performing the backhand stroke: implications for tennis elbow. J Biomech 1994;27:509-16.

72 Wu SK, Gross MT, Prentice WE, et al. Comparison of ball-and-racquet impact force between two tennis backhand stroke techniqes. J Orthop Sports Phys Ther 2001;31:247-54.

73 Riek S, Chapman AE, Milner T. A simulation of muscle force and internal kinematics of extensor carpi radialis brevis during backhand tennis stroke: implications for injury. Clin Biomech (Bristol) 1999;14:477-83.

74 Bahamonde RE, Knudson D. Kinetics of the upper extremity in the open and square stance tennis forehand. J Sci Med Sport 2003;6:88-101.

75 Knudson D, Blackwell J. Upper extremity angular kinematics of the onehanded backhand drive in tennis players with and without tennis elbow. Int J Sports Med 1997; 18:79-82.

76 Kleinöder H, Mester J. [Stress for the hitting arm by wrist and forearm actions in tennis]. Dtsch Z Sportmed 1998;49:217-20.

77 Marshall RN, Elliott BC. Long-axis rotation: the missing link in proximal-todistal segmental sequencing. J Sports Sci 2000;18:247-54.

78 Knudson DV. Factors affecting force loading on the hand in the tennis forehand. J Sports Med Phys Fitness 1991;31:527-31.

79 Kelley JD, Lombardo SJ, Pink $M$, et al. Electromyographic and cinematographic analysis of elbow function in tennis players with lateral epicondylitis. Am J Sports Med 1994;22:359-63.

80 Ryu RK, McCormick J, Jobe FW, et al. An electromyographic analysis of shoulder function in tennis players. Am J Sports Med 1988;16:481-5.

81 Morris M, Jobe FW, Perry J, et al. Electromyographic analysis of elbow function in tennis players. Am J Sports Med 1989;17:241-7.

82 Giangarra CE, Conroy B, Jobe FW, et al. Electromyographic and cinematographic analysis of elbow function in tennis players using singleand double-handed backhand strokes. Am J Sports Med 1993:21:394-9.

83 Baver JA, Murray RD. Electromyographic patterns of individuals suffering from lateral tennis elbow. J Electromyogr Kinesiol 1999;9:245-52.

84 Stroede CL, Noble L, Walker HS. The effect of tennis racket string vibration dampers on racket handle vibrations and discomfort following impacts. J Sports Sci 1999;17:379-85.

85 Hatze $\mathbf{H}$. The effectiveness of grip bands in reducing racquet vibration transfer and slipping. Med Sci Sports Exerc 1992;24:226-30.

86 Hennig EM, Rosenbaum D, Milani TL. Transfer of tennis racket vibrations onto the human forearm. Med Sci Sports Exerc 1992;24:1134-40.

87 Strizak AM, Gleim GW, Sapega A, et al. Hand and forearm strength and its relation to tennis. Am J Sports Med 1983;11:234-9.

88 Colak T, Bamac B, Ozbek A, et al. Nerve conduction studies of upper extremities in tennis players. Br J Sports Med 2004;38:632-5.

89 Brasseur JL, Lucidarme O, Tardieu M, et al. Ultrasonographic rotator-cuff changes in veteran tennis players: the effect of hand dominance and comparison with clinical findings. Eur Radiol 2004; 14:857-64.

$90 \mathrm{Vad}$ VB, Gebeh A, Dines D, et al. Hip and shoulder internal rotation range of motion deficits in professional tennis players. J Sci Med Sport 2003:6:71-5.

91 Stussi E, Stacoff A. [Biomechanical and orthopedic problems of tennis and indoor sports shoe]. Sportverletz Sportschaden 1993;7:187-90.

92 Krabbe B, Farkas R, Baumann W. [Stress on the upper ankle joint in tennisspecific forms of movement]. Sportverletz Sportschaden 1992;6:50-7. 
93 Simpson KJ, Shewokis PA, Alduwaisan S, et al. Factors influencing rearfoot kinematics during a rapid lateral braking movement. Med Sci Sports Exerc 1992;24:586-94.

94 Nigg B, Segesser B. The influence of playing surfaces on the load on the locomotor system and on football and tennis injuries. Sports Med 1988;5:375-85

95 Luethi S, Frederick E, Hawes M, et al. Influence of shoe construction on lower extremity kinematics and load during lateral movements in tennis. Int J Biomech 1986;2:166-74.

96 Reinschmidt C, Nigg BM. Current issues in the design of running and court shoes. Sportverletz Sportschaden 2000;14:71-81.

97 Knudson D, Blackwell J. Trunk muscle activation in open stance and square stance tennis forehands. Int J Sports Med 2000;21:321-4.

98 Roetert E, McCormick T, Brown S, et al. Relationship between isokinetic and functional trunk strength in elite junior tennis players. Isokinetics Exerc Sci 1996;6:15-20.

99 Dalichau S, Scheele K. [Influence of sports mechanic demands in competitive tennis on the thoracolumbar spinal profile]. Sportverletz Sportschaden 2002; 16:64-9.

100 Chandler T, Ellenbecker T, Roetert E. Sport-specific muscle strength imbalances in tennis. Strength Condition 1998;20:7-10.

101 Goodman B, Berke M, Schwartz L. The biomechanics of tennis injuries. Phys Med Rehabil State Art Rev 1997;1 1:675-95.

102 Chandler TJ, Kibler WB, Uhl TL, et al. Flexibility comparisons of junior elite tennis players to other athletes. Am J Sports Med 1990;18:134-6.

103 Kraemer W, Triplett N, Fry A, et al. An in-depth sports medicine profile of women college tennis players. J Sport Rehabil 1995;4:79-98.

104 Vriend I, Van Kampen B, Schmikli S, et al. Ongevallen en Bewegen in Nederland 2000-2003. Ongevalsletsels en sportblessures in kaart gebracht. Amsterdam: Consument en Veiligheid, 2005.

105 Jayanthi N, Sallay $P$, Hunker $P$, et al. Skill-level related injuries in recreational competition tennis players. Med Sci Tennis 2005;10:12-15.

106 Kuhne C, Zettl R, Nast-Kolb D. [Injuries- and frequency of complaints in competitive tennis- and leisure sports]. Sportverletz Sportschaden 2004; 18:85-9.

107 Silva RT, Takahashi R, Berra B, et al. Medical assistance at the Brazilian juniors tennis circuit-a one-year prospective study. J Sci Med Sport 2003:6:14-18.

108 Letsel Informatie Systeem 1999-2003. Amsterdam: Consument en Veiligheid, 2004.

109 Schmikli S, De Wit M, Backx F. Sportblessures driemaal geteld. Kernciifers en trends uit landelijk onderzoek naar sportblessures in Nederland. Arnhem: NOC*NSF, 2001

110 Sallis RE, Jones K, Sunshine S, et al. Comparing sports injuries in men and women. Int J Sports Med 2001;22:420-3.

111 Steinbruck K. [Epidemiology of sports injuries-25-year-analysis of sports orthopedic-traumatologic ambulatory care]. Sportverletz Sportschaden $1999 ; 13: 38-52$

112 Weijermans N, Backx F, Van Mechelen W. Blessures bij outdoor-tennis. Geneesk Sport 1998;3:95-9.

113 Hutchinson MR, Laprade RF, Burnett QM, et al. Injury surveillance at the USTA Boys' Tennis Championships: a 6-yr study. Med Sci Sports Exerc 1995; 27:826-30.

114 Baxter-Jones AD, Maffulli N, Helms P. Low injury rates in elite athletes. Arch Dis Child 1993;68:130-2.

115 Lanese RR, Strauss RH, Leizman DJ, et al. Injury and disability in matched men's and women's intercollegiate sports. Am J Public Health 1990;80:1459-62.

116 Winge S, Jorgensen U, Lassen Nielsen A. Epidemiology of injuries in Danish championship tennis. Int J Sports Med 1989:10:368-71

117 Krause R, Pöttinger P. Tennisverletzungen von Leistungsspielern. Prakt SportTraumatol Sportmed 1988;1:47-9.

118 Chard MD, Lachmann SM. Racquet sports-patterns of injury presenting to a sports injury clinic. Br J Sports Med 1987;21:150-3.

119 Reece L, Fricker P, Maguire K. Injuries to elite young tennis players at the Australian Institute of Sports. Aust J Sci Med Sport 1986;18:11-15.

120 Von Salis-Soglio G. Sportverletzungen und Sportschäden beim Tennis. Dtsch Z Sportmed 1979;29:244-8.
121 von Krämer J, Schmitz-Beuting J. Überlastungsschäden am Bewegungsapparat bei Tennisspielern. Dtsch Z Sportmed 1979;2:44-6

122 Biener K, Caluori P. Sportmedizinischer Profil des Tennisspielers. Sportarzt Sportmed 1976:8:198-202.

123 Biener K, Caluori P. Sportmedizinischer Profil des Tennisspielers. Sportarzt Sportmed 1976;9:227-9.

124 Biener K, Caluori P. Sportmedizinischer Profil des Tennisspielers. Sportarzt Sportmed 1976;10:254-5.

125 Hang YS, Peng SM. An epidemiologic study of upper extremity injury in tennis players with a particular reference to tennis elbow. Taiwan Yi Xue Hui Za Zhi 1984;83:307-16

126 Lo YP, Hsu YC, Chan KM. Epidemiology of shoulder impingement in upper arm sports events. Br J Sports Med 1990;24:173-7.

127 Kamien M. Tennis elbow in long-time tennis players. Aust J Sci Med Sport 1988;20:19-27

128 Gruchow HW, Pelletier D. An epidemiologic study of tennis elbow. Incidence, recurrence, and effectiveness of prevention strategies. Am J Sports Med 1979:7:234-8.

129 Kitai E, Itay S, Ruder A, et al. An epidemiological study of lateral epicondylitis (tennis elbow) in amateur male players. Ann Chir Main 1986;5:113-21.

130 Carroll R. Tennis elbow: incidence in local league players. Br J Sports Med $1981 ; 15: 250-6$

131 Priest J, Braden V, Goodwin Gerberich S. The elbow and tennis, Part 1. An analysis of players with and without pain. Physician Sportsmed 1980:8:81-91.

132 Priest J, Braden V, Goodwin Gerberich S. The elbow and tennis, Part 2. Study of players with pain. Physician Sportsmed 1980;8:77-85.

133 Feit EM, Berenter R. Lower extremity tennis injuries. Prevalence, etiology, and mechanism. J Am Podiatr Med Assoc 1993;83:509-14.

134 Saraux A, Guillodo Y, Devauchelle V, et al. Are tennis players at increased risk for low back pain and sciatica? Rev Rhum Engl Ed 1999;66:143-5.

135 Spector TD, Harris PA, Hart DJ, et al. Risk of osteoarthritis associated with long-term weight-bearing sports: a radiologic survey of the hips and knees in female ex-athletes and population controls. Arthritis Rheum 1996;39:988-95

136 Nigg $B$, Frederick $E$, Hawes $M$, et al. Factors influencing short-term pain and injuries in tennis. Int J Sport Biomech 1986;2:156-65.

137 Llana S, Brizuela G, Dura JV, et al. A study of the discomfort associated with tennis shoes. J Sports Sci 2002;20:671-9.

138 Junge $\mathbf{A}$, Langevoort $G$, Pipe $A$, et al. Injuries in team sport tournament during the 2004 Olympic Games. Am J Sports Med 2005;34:1-12.

139 Gosheger G, Liem D, Ludwig K, et al. Injuries and overuse syndromes in golf. Am J Sports Med 2003;31:438-43.

140 Marti B, Minder C, Abelin T. On the epidemiology of running injuries. The 1984 Bern Grand Prix study. Am J Sports Med 1988;16:285-94.

141 Taunton J, Ryan M, Clement D, et al. A prospective study of running injuries: the Vancouver Sun Run "In Training" clinics. Br J Sports Med 2003;37:239-44

142 Kibler WB, Chandler TJ. Range of motion in junior tennis players participating in an injury risk modification program. J Sci Med Sport 2003;6:51-62.

143 Herbert R, Gabriel M. Effects of stretching before and after exercising on muscle soreness and risk of injury: systematic review. BMJ 2002;325:468.

144 Orchard J, Seward H. Epidemiology of injuries in the Australian Football League, seasons 1997-2000. Br J Sports Med 2002;36:39-44.

145 Hagglund M, Walden M, Bahr R, et al. Methods for epidemiological study of injuries to professional football players: developing the UEFA model. Br J Sports Med 2005;39:340-6.

146 McManus A. Validation of an instrument for injury data collection in rugby union. Br J Sports Med 2000;34:342-7.

147 Meeuwisse W, Love E. Development, implementation, and validation of the Canadian Intercollegiate Sport Injury Registry. Clin J Sport Med 1998;8:164-77.

148 Van Mechelen W, Twisk J, Molendiik A, et al. Subject-related risk factors for sports injuries: a 1-yr prospective study in young adults. Med Sci Sports Exerc 1996;28:1171-9 